\title{
Studi InVivo Ekstrak Daun Teh Hijau (Camellia sinensis) sebagai Alternatif Anti Eschericia coli pada Ayam Broiler
}

\section{In-Vivo Study of Green Tea Leaf Extract (Camellia sinensis) as an Alternative Anti-Eschericia coli in Broiler Chickens}

\author{
Bambang Sutrisno*, R. Wasito, Kurniasih, Sitarina Widyarini, Yuli Purwandari Kristianingrum, Sugiyono \\ Departemen Patologi, Fakultas Kedokteran Hewan, Universitas Gadjah Mada, \\ Jl. Fauna 2 Karangmalang, Sleman, Yogyakarta 55281 \\ *Email: bambangsutrisno@ugm.ac.id
}

Naskah diterima: 11 April 2019, direvisi: 26 Agustus 2019, disetujui: 30 November 2019

\begin{abstract}
The prevalence of colibasillosis in poultry farm in Indonesia is very high, while bacteria have a natural ability to develop antibiotic resistance, and the resistance has eventually been occurred to nearly all antibiotics that have been developed up to the present so that it is necessary to look for the alternatives to replace antibiotics as antibacterial prevention and treatment. The study was aimed to determine the antibacterial effect of green tea leaf extract on broiler chickens infected with Eschericia coli by determining the score of macroscopic and histopathological lesions, and heterophils, plasma protein, and blood fibrinogen level as well. In the present study, 20 broiler chickens were used and randomly allotted into 4 groups (Groups A, B, C and D) of 5 each. All broiler chickens were given ND and Gumboro vaccines on schedule as usual for maintaining broiler chickens' health on a daily basis. Starting at the age of 21 days, all broilers chickens in each group: Groups Control (A), B. C and D that were not infected with E. coli and were not given water extract of green tea leaf (Camillia sinensis), infected intra-tracheally with local strains of E.coli $10^{8}$ cells / $\mathrm{ml}$ according to $0,5 \mathrm{Mc}$ Farland standard, and were not given water extract of green tea leaf (Camillia sinensis), infected intratracheally with local strains of $E$. coli $10^{8}$ cells / $\mathrm{ml}$ by $0,5 \mathrm{Mc}$ Farland standard, and given to drink water extract of green tea leaf (Camillia sinensis) $0,1 \mathrm{~g} / \mathrm{ml}$ and were given to drink water extract of green tea leaf (Camillia sinensis) $0,1 \mathrm{~g} / \mathrm{ml}$, respectively. During the treatment all of chickens were given food and drink ad libitum. Fourteen days after infection of E.coli, 5 chickens in each group were collected to withdrawal the blood from wing vein for examination of heterophils, TPP (total protein plasma) and fibrinogen. After that, the chickens were euthanasied with $\mathrm{Mg} \mathrm{SO} 4$ saturated solution intravenously and then necropsied for gross and histopathological examinations. Analysis of the results of the blood examination were applied one way of anova (SPSS version 22 program), whereas the gross and histopathological examination were analyzed descriptively. Results of the present study showed that the gross and histopathological examinations of the brolier chickens' organ infected with $E$. coli without being given a green tea extract had airsacculitis, pericarditis, perihepatitis, and peritonitis, whereas broiler chickens infected with $E$. coli and given green tea extract does not indicate the inflammation in any organs. Examination of heterophils counts and blood fibrinogen levels had shown a difference $(\mathrm{P}<0.05)$. Broilers chickens infected with $E$. coli and given green tea extracts had lower amounts of heterophils and fibrinogen levels than that of without given a water extract of the green tea. While blood TPP levels were not significantly different $(\mathrm{P}>0.05)$ among the groups. It is concluded the study in vivo of the green tea extract (Camelia sinensis) $0,1 \mathrm{~g} / \mathrm{ml}$ has the potential to inhibit the infection of $E$. coli in infected broiler chickens.
\end{abstract}

Key words: antibacterial; broiler chickens; Eschericia coli; extract of green tea leaves

\begin{abstract}
Abstrak
Prevalensi kolibasilosis pada peternakan ayam di Indonesia sangat tinggi, pengobatan menggunakan antibiotik mengalami kendala adanya resistensi, maka perlu dicari alternatif pengganti antibiotik. Penelitian ini ditujukan untuk mengetahui efek anti bakteri ekstrak daun teh hijau terhadap ayam broiler yang diinfeksi Eschericia coli. dengan melihat score lesi makroskopik yang di perkuat dengan pemeriksaan histopatologis,
\end{abstract}


pemeriksaan heterofil, protein plasma dan fibrinogen. Penelitian digunakan 20 ekor broiler yang dibagi secara acak ke dalam 4 kelompok yaitu kelompok A, B, C dan D yang masing-masing terdiri 5 ekor broiler. Vaksinasi ND dan Gumboro dilakukan sesuai jadwal seperti pemeliharaan pada umumnya. Pada umur 21 hari seluruh broiler pada masing-masing kelompok mulai diperlakukan sebagai kontrol (Kelompok A) tanpa infeksi E. coli dan tidak diberi minum ekstrak air daun teh hijau (Camillia sinensis). Kelompok B, broiler diinfeksi secara intratracheal dengan bakteri E.coli strain lokal $10^{8} \mathrm{sel} / \mathrm{ml}$ menurut standar Mc Farland 0,5, dan tidak diberi minum ekstrak daun teh. Kelompok C, broiler diinfeksi secara intratracheal dengan bakteri E. coli strain lokal $10^{8} \mathrm{sel} / \mathrm{ml}$ menurut standar Mc Farland 0,5, dan diberi minum ekstrak daun teh hijau (Camillia sinensis) 0,1g/ ml. Kelompok D, broiler diberi minum ekstrak daun teh hijau (Camillia sinensis) 0,1g/ml. Selama perlakukan ayam masing-masing kelompok diberi pakan dan minum secara ad libitum. Empat belas hari setelah infeksi $E$. coli, ayam pada masing-masing kelompok diambil 5 ekor untuk dikoleksi darah untuk pemeriksaan heterofil, total protein plasma (TPP) dan fibrinogen. Selanjutnya ayam dietanasi dengan injeksi larutan Mg SO4 jenuh secara intravena dan dinekropsi guna pemeriksaan patologi makroskopik untuk skoring lesi, kemudian dilakukan pengambilan jaringan untuk pemeriksaan histopatoplogik. Analisis hasil penelitian untuk pemeriksan darah menggunakan one way of Anova (program SPSS versi 22), sedangkan pemeriksan makroskopik dan mikroskopik dianalisis dengan diskriptif kualitatif. Hasil penelitian menunjukkan bahwa pemeriksaan makroskopik dan mikroskopik organ brolier yang hanya dinfeksi E.coli tanpa diberi ekstrak teh hijau mengalami airsacculitis, pericarditis, perihepatitis dan peritonitis, sedangkan broiler yang diinfeksi E.coli dan diberi ekstrak teh hijau tidak menunjukkan adanya peradangan. Hasil pemeriksaan jumlah heterofil dan kadar fibrinogen darah lebih rendah secara signifikan $(\mathrm{P}<0,05)$ dibanding dengan broiler yang diinfeksi E.coli tanpa diberi ektak teh hijau, sedangkan kadarTPP darah tidak berbeda nyata $(\mathrm{P}>0,05)$. Kesimpulan, ekstrak teh hijau (Camelia sinensis) $0,1 \mathrm{~g} /$ $\mathrm{ml}$ memiliki potensi menghambat infeksi bakteri Eschericia coli pada ayam broiler.

Kata kunci: antibakteri; broiler; ekstrak daun teh hijau; Eschericia coli

\section{Pendahuluan}

Avian pathogenic Escherichia coli (APEC) sebagai penyebab utama kolibasillosis pada unggas. Penyakit ini umum terjadi pada peternakan ungas khususnya pada peternakan unggas intensif di seluruh dunia dan mengenai semua umur. Penyakit ini memiliki dampak ekonomi di peternakan unggas secara luas (Ronco et al., 2017). Kolibasilosis unggas dapat menular ke manusia, meskipun kebanyakan strain E.coli tidak dianggap sebagai patogen, beberapa dapat juga bertidak sebagai patogen oportunistik yang menyebabkan infeksi pada hospes yang immunokompromis. Beberapa strain patogenik dapat menyebabkan gangguan gastrointestinal pada manusia sehat dan hewan (Matin et al., 2017).

Prevalesi kejadian kolibasillosis cukup tinggi di industri peternakan ayam, di Mesir kejadian kolibasillosis mencapai $44 \%$ pada peternakan ayam broiler ex import, sedangkan $75 \%$ pada peternakan ayam broiler lokal (El-Tawab et al., 2015). Demikian juga kejadian kolibasillosis di Mymensingh, Banglades $1 \%$ pada ayam broiler umur antara $25-30$ hari, dan $0,5 \%$ pada broiler umur antara 31 - 35 hari (Matin et al., 2017), di Indonesia kejadian kolibasillosis 22,2 $\%$ dibanding penyakit lain pada ayam (Wiedosari dan Wahyuwardani, 2015).
Penggunaan antibiotik sebagai terapi antimikrobia merupakan obat untuk menurunkan kejadian dan mortalitas terkait dengan kolibasillosis pada unggas. Walaupun kebaradaan E. coli resisten terhadap antibiotik berkembang secara luas di dunia, terlebih terkait dengan E. coli penyebab penyakit pada unggas. Di China, bakteri Escherichia coli asal hewan termasuk ayam sudah mulai resisten terhadap tetracycline, nalidic acid, sulfamethoxazole, trimetoprim/sulfamethoxazole dan ampicilin, bahkan mulai meningkat resistensinya terhadap amikacin, aztreonam, ceftazidime, cefotaxime, chloramphenicol, ciprofloxacine dan amoxicillin/ clavulanic acid (Yassin et al., 2017). Serupa juga di Mesir E. coli yang diisolasi dari ayam telah terbukti resisten terhadap antibiotik $\beta$-lactam, erytromycin, florfenicol, gentamycin, dan ciprofloxacin ( El Tawab et al., 2015). Di Indonesia, isolat E.coli dari air sungai dan air rumah tangga sepanjang Sungai Code juga telah terbukti ada resistensi terhadap antibiotik amoksisilin, kloramfenikol, sulfametoxazol dan streptomycin (Sasongko, 2014), sedangkan di Aceh E. coli yang terisolasi dari ayam broiler di pasar Rukoh juga telah terbukti sudah resisten terhadap beberapa antibiotik seperti streptomisin, eritromisin, ampisilin, tetrasiklin, gentamisin, ciprofloxacin dan sulfametoksasol (Mukti, et al., 2017). 
Pengunaan ekstrak tanaman yang secara tradisional telah mampu digunakan sebagai antimikrobia merupakan alternatif sebagai pengganti antibiotik. Teh hijau (Camellia sinensis) merupakan tanaman daerah tropis dan sub tropis termasuk famili Theaceae. Minuman teh dapat di buat dari akar, batang, dan daun (Segneanu et al., 2012). Teh hijau umumnya aman, tidak toksik dan tidak ada side effect untuk di konsumsi (Padmini et al., 2011). Daun teh kering memiliki senyawa aktif seperti saponin, glikosida, steroid, terpenoid, carotenoid, flavonoid, alkaloid, dan tanin yang mana sebagai penyedia substansi obat (Akowuah et al., 2005). Kebanyakan aksi biologiknya seperti obat penurun lemak darah, anti radang, antimikrobia, anticancer, dan antioksidan yang terkait dengan fraksi polifenol seperti catechin teh (Bohm, 1998; Jankun et al., 1997 dan Kumar et al., 2012) serta sebagai antiprotozoa (Paveto et al., 2004). Pada konsentrasi rendah epigallocatechin gallate dan epicatechin gallate dapat menekan faktor virulensi bakteri dan dapat membunuh Staphylococcus aureus patogen oportunis yang resisten terhadap antibiotik $\beta$-lactam (Peter et al., 2005). Kemampuan aktivitas senyawa tersebut terbukti juga terhadap berbagai mikrobia patogen lain seperti virus hepatitis (Rivero-Buceta et al. 2015)dan HIV (Yamaguchiet al., 2002), clamydia dan mycoplasma (Chosa et al., 1992), rotavirus, enterovirus dan influenza (Song et al., 2005), fungi filamentous (Okubo et al., 1991) dan yeast (Herasawa dan Takada, 2004). Berbagai suvei epidemiologis telah menunjukkan bahwa konsumsi teh hijau terkait dengan rendahnya kejadian berbagai kondisi patologis termasuk penyakit kardiovaskuler seperti stroke, obesitas dan cancer (Hertog et al., 1993 dan Keli et al., 1995). Pengujian ekstrak daun teh hijau dengan air dingin secara invitro mengunakan metode difusi telah terbukti mampu menghambat pertumbuhan bakteri Salmonella typhi, Escherichia coli dan Staphylococcus aureus (Majid et al., 2013), bahkan dengan penambahan $10 \mu 1,20 \mu \mathrm{l}$ dan $30 \mu \mathrm{l}$ ekstrak teh hijau pada media difusi memiliki aktivitas anti bakteri sangat signifikan (Kumar et al., 2012).

Tujuan penelitian adalah untuk mengetahui efek anti bakteri ekstrak daun teh hijau terhadap ayam broiler yang diinfeksi Eschericia coli dengan melihat skor lesi makroskopik, di perkuat dengan pemeriksaan histopatologis organ terlibat, pemeriksaan heterofil dan total protein plasma serta fibrinogen.

\section{Materi dan Metode}

\section{Bahan}

Penelitian ini menggunakan 20 ekor ayam broiler (Janu Putra, Yogyakarta) dengan umur 1 hari, bakteri E. coli isolat lokal (koleksi Lab. Mikrobiologi FKH UGM), bahan lain yang digunakan adalah spuit $1 \mathrm{cc}$ dan spuit 2,5 cc (Terumo) masing-masing 30 buah, tabung ependorf 60 buah, serta kontainer yang berisi buffer formalin $10 \%$ (Merck, Germany) sebanyak 20 buah, dalam penelitian ini juga menggunakan enam kandang yang terbuat dari bambu.

\section{Alat}

Peralatan yang dipakai adalah dua set alat nekropsi, timbangan berat badan ayam (Sartorius, Germany), prosesing jaringan (Leica, Germany), rotary mikrotome (Yamato, Japan), staining jar dan mikroskop (Olympus, Japan).

\section{Cara Penelitian}

Penelitian menggunakan 20 ekor broiler yang dibagi secara acak ke dalam 4 kelompok yaitu kelompok A, kelompok B, kelompok C, dan kelompok D yang masing-masing terdiri 5 ekor broiler. Semua ayam yang digunakan dilakukan vaksinasi ND dan Gumboro sesuai jadwal seperti pemeliharaan pada umumnya. Pada umur 21 hari seluruh broiler pada masing-masing kelompok mulai diperlakukan. Kelompok kontrol (Kelompok A) tanpa infeki $E$. coli dan tidak diberi minum ekstrak air daun teh hijau (Camillia sinensis) 0,1g/ml. Kelompok B, broiler diinfeksi secara intratracheal dengan bakteri E. coli strain lokal $10^{8} \mathrm{sel} / \mathrm{ml}$ menurut standar $M c$ Farland 0,5, dan tidak diberi minum ekstrak daun teh hijau hingga perlakuan berakhir. Kelompok C, broiler diinfeksi secara intratracheal dengan bakteri E.coli strain lokal $10^{8} \mathrm{sel} / \mathrm{ml}$ menurut standar $M c$ Farland 0,5, dan diberi minum ekstrak daun teh hijau (Camillia sinensis) 0,1g/ml, dan Kelompok D, broiler diberi minum ekstrak daun teh hijau (Camillia sinensis) $0,1 \mathrm{~g} / \mathrm{ml}$. Selama perlakuan ayam masingmasing kelompok diberi pakan dan minum secara $a d$ libitum. Empat belas hari setelah infeksi E. coli, ayam pada masing-masing kelompok diambil 5 ekor untuk dikoleksi darah untuk pemeriksaan heterofil, TPP, dan fibrinogen. Selanjutnya ayam dietanasi dan dinekropsi guna pemeriksaan patologi makroskopik untuk skoring 
lesi serta selanjutnya dilakukan pengambilan jaringan untuk pemeriksaan histopatoplogik dengan mikroskop.

\section{Analisis Hasil}

Hasil pemeriksaan darah dan skor lesi makroskopik terhadap masing-masing kelompok ayam dianalisis statistik menggunakan rancangan percobaan One-Way Anova mengunakan program statistik SPSS versi 22. Perubahan histopatologi dianalisis dengan diskriptif kualitatif.

\section{Hasil dan Pembahasan}

Uji in-vivo pemberian ekstrak air teh hijau $0,1 \mathrm{~g} /$ $\mathrm{ml}$ pada ayam broiler yang diinfeksi E. coli $10^{8} \mathrm{sel} /$ $\mathrm{ml}$ standar Mc. Farland 0,5 telah menunjukkan kemampuan hambatan terhadap infeksi E.coli pada broiler, sedangkan kelompok ayam yang hanya diinfeksi E. coli tanpa pemberian ekstrak air teh hijau semua menunjukkan adanya air sacculitis, pericarditis, perihepatitis dan peritonitis, sementara ayam kelompok lain yakni kontrol dan kelompok pemberian teh hijau saja tidak menunjukkan adanya lesi spesifik kolibasilosis (Tabel 1.). Perubahan lesi makroskopik ayam positif terinfeksi $E$. coli, berupa kekeruhan air sacc (kantong udara), terdapat eksudat berfibrin atau bahkan terdapat eksudat kaseosa (Gambar.1 B), bagian tepi lobus hepar dan perikardium jantung mengalami keradangan dengan eksudat berfibrin, organ limfoid termasuk lien, timus dan Bursa Fabricius terlihat
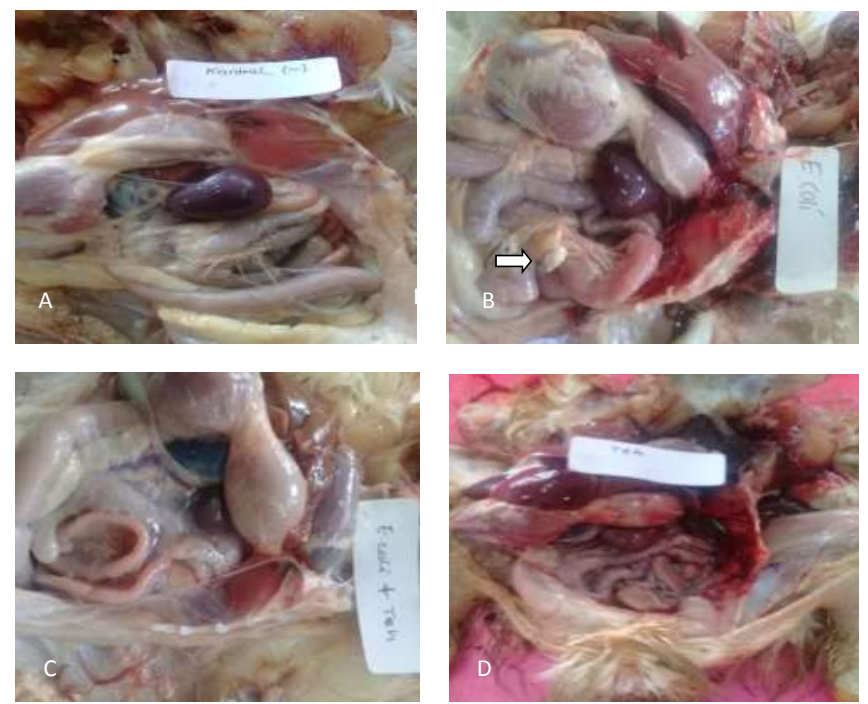

Gambar 1. Lesi Makroskopik ayam broiler 14 hari setelah infeksi Escherichia coli $10^{8} \mathrm{sel} / \mathrm{ml}$ standar Mc. Farland 0,5 dan diberi ekstrak daun the hijau 0,1g/ $\mathrm{ml} \mathrm{A}$ : Kontrol (Negatif), B: Kelompok ayam hanya di infeksi E.coli (positif), terdapat eksudat kaseosa pada air sacc ( ), C : (Negatif) dan D: (Negatif) sedikit mengalami pembesaran ukuran terutama pada broiler yang diinfeksi E. coli saja. Perubahan tersebut merupakan lesi akibat kolibasilosis pada ayam sesuai pendapat Barnes and Gross (1997) bahwa infeksi lokal ataupun sistemik Escherechia coli pada ayam termasuk coliseptisemia, coligranuloma (Hjarre's disease), airsacculitis (Chronic Respiratory Disease), avian cellulitis,swollen head syndrome, peritonitis, salpingitis, osteomyelitis/synovitis, panopthalmitis dan omphalitis.

Hasil pemeriksaan histopatologis hepar dan jantung broiler (kelompok B) setelah 14 hari dinfeksi $E$. coli menunjukkan infiltrasi heterofil di daerah trigonum kiernan (Gambar 2. A), tetapi kelompok C, ayam yang diinfeksi E. coli dan diberi ekstrak air teh hijau $0,1 \mathrm{~g} /$ $\mathrm{ml}$ tidak menunjukkan keradangan dan nekrosis hepar, air sacc, dan peritoneum (Tabel 2. dan Gambar 2. B). Sedangakan pemeriksaan organ lain kelompok B, yaitu jantung dan organ limfoid broiler yang diinfeksi $E$

Tabel 1. Score lesi pada organ broiler 14 hari setelah infeksi Escherichia coli $10^{8} \mathrm{sel} / \mathrm{ml}$ standar Mc. Farland 0,5 dan diberi ekstrak daun teh hijau $10 \mathrm{~g} / 100 \mathrm{ml}$

\begin{tabular}{|c|c|c|c|c|}
\hline Kode & Airsacculitis & perihepatitis & Perikarditis & Peritonitis \\
\hline 1 & - & - & - & - \\
\hline 2 & - & - & - & - \\
\hline $3(\mathrm{~A})$ & - & - & - & - \\
\hline 4 & - & - & - & - \\
\hline 5 & - & - & - & - \\
\hline 1 & + & - & - & + \\
\hline 2 & +++ & ++ & ++ & +++ \\
\hline $3(\mathrm{~B})$ & ++ & + & ++ & ++ \\
\hline 4 & + & - & - & + \\
\hline 5 & + & - & - & + \\
\hline 1 & - & - & - & - \\
\hline 2 & - & - & - & - \\
\hline $3(\mathrm{C})$ & - & - & - & - \\
\hline 4 & - & - & - & - \\
\hline 5 & - & - & - & - \\
\hline 1 & - & - & - & - \\
\hline 2 & - & - & - & - \\
\hline 3 (D) & - & - & - & - \\
\hline 4 & - & - & - & - \\
\hline 5 & - & - & - & - \\
\hline
\end{tabular}

Keterangan :

- $\quad$ : tidak ditemukan adanya keradangan

$+\quad$ : ada keradangan ringan berupa kekeruhan

++ : ada keradangan yang ditandai eksudat berfibrin

+++ : ada keradangan yang ditandai eksudat kaseosa atau granulomatosa 

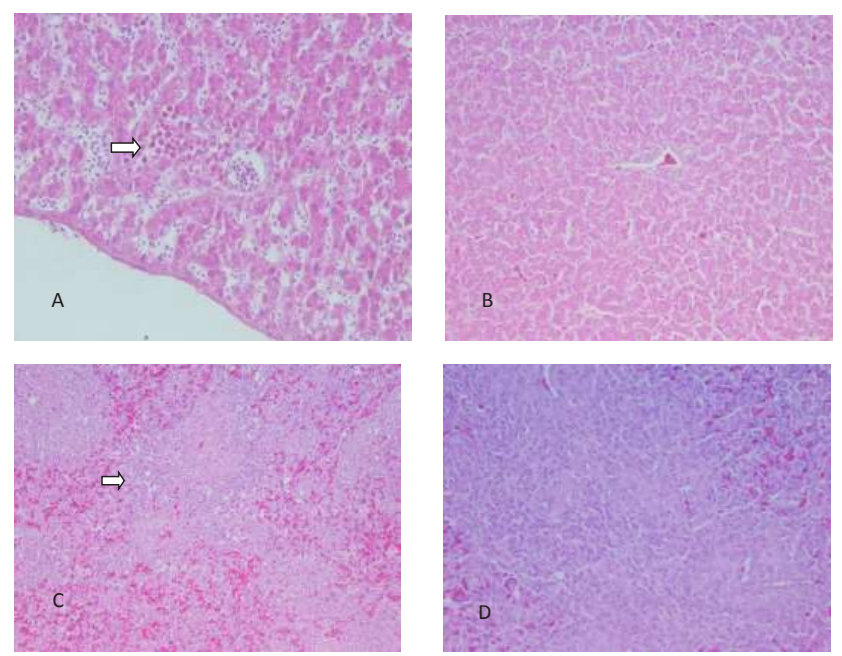

Gambar 2. Histopatologis organ broiler 14 hari setelah infeksi Escherichia coli $10^{8} \mathrm{sel} / \mathrm{ml}$ standar Mc. Farland 0,5 dan diberi ekstrak daun teh hijau $0,1 \mathrm{~g} / \mathrm{ml}, \mathrm{A}$ : organ hepar positif terinfeksi E.coli ada infiltrasi heterofil di sekitar trigonum kiernan $(\Rightarrow)$, B : organ hepar negatif kolibasilosis (normal), $\mathrm{C}$ : organ lien positif terinfeksi E. coli, limfosit mengalami deplesi $(\Longrightarrow)$ dan D : organ lien negatif kolibasilosis

.coli menyebabkan pericarditis jantung serta nekrosis dan deplesi limfosit organ limfoid seperti lien (Gambar 2. C), bursa Fabricius, dan timus (Tabel 2).

Lesi tersebut juga dikemukakan oleh Abalaka et al. (2017) bahwa infeksi E. coli ayam menyebabkan kongesti, nekrosis multifokal dan infiltasi selular pada hepar, deplesi limfosit lien, infiltrasi selular dan nekrosis otot jantung. Adanya perbedaan ini menunjukkan bahwa efek ekstrak daun teh hijau 0,1 $\mathrm{g} / \mathrm{ml}$ mampu mencegah terjadinya keradangan akibat infeksi E. coli seperti pada kelompok B.

Hasil pemeriksaan histopatologis organ ayam broiler kelompok C (Tabel 2) menunjukkan hasil yang sama dengan pemeriksaan makroskopik organ broiler, bahwa pemberian ekstrak teh hijau mampu menghambat infeksi, sehingga tidak terjadi keradangan pada organ-organ target.

Hasil analisis statistik jumlah heterofil darah perifer broiler pada berbagai kelompok telah menunjukkan perbedaan nyata $(\mathrm{P}<0,05)$, kelompok $\mathrm{C}$ adalah kelompok broiler yang diinfeksi $E$. coli dan diberi ekstrak teh hijau $0,1 \mathrm{~g} / \mathrm{ml}$ menunjukkan hasil sebesar $3,7 \times 10^{3} \mathrm{sel} / \mathrm{mm}^{3}$, jumlah tersebut lebih kecil dari jumlah heterofil broiler kelompok B, kelompok infeksi E.coli menunjukkan jumlah paling tinggi yaitu $16,9 \times 10^{3} \mathrm{sel} / \mathrm{mm}^{3}$ jauh di atas normal yakni 3 - $6 \times 10^{3} \mathrm{sel} / \mathrm{mm}^{3}$ (Weis dan Wardrop, 2010). Hal ini membuktikan, bahwa pemberian ekstrak teh hijau 0,1
Tabel 2. Pemeriksaan histopatologi organ broiler 14 hari setelah infeksi Escherichia coli $10^{8} \mathrm{sel} / \mathrm{ml}$ standar Mc. Farland 0,5 dan diberi ekstrak daun teh hijau $0,1 \mathrm{~g} / \mathrm{ml}$

\begin{tabular}{lccccc}
\hline Kode & Hepar & Jantung & Lien & Timus & Bursa Fabricius \\
\hline 1 & - & - & - & - & - \\
$2($ A) & - & - & - & - & - \\
3 & - & - & - & - & - \\
1 & + & + & + & + & + \\
$2(B)$ & ++ & + & + & + & + \\
3 & + & + & + & + & + \\
1 & - & - & - & - & - \\
$2(\mathrm{C})$ & - & - & - & - & - \\
3 & - & - & - & - & - \\
1 & - & - & - & - & - \\
2 (D) & - & - & - & - & - \\
3 & - & - & - & - & - \\
\hline
\end{tabular}

Keterangan :

- : tidak ditemukan adanya keradangan

+ : ada keradangan ringan berupa infiltrasi heterofil di organ hepar dan jantung, dan terjadi deplesi limfosit pada organ limfoid

++: ada keradangan kronis yang disertai nekrosis jaringan

$\mathrm{g} / \mathrm{ml}$ mampu menekan heterofilia pada broiler yang diinfeksi E. coli, seperti terlihat pada Gambar 3. Broiler kelompok kontrol (A) dan kelompok (D) yang diberi teh saja, tampak jumlah heterofil paling rendah $1,4 \mathrm{x}$ $10^{3} \mathrm{sel} / \mathrm{mm}^{3}$ dan $0,7 \times 10^{3} \mathrm{sel} / \mathrm{mm}^{3}$. Infeksi bakterial akan menyebabkan jumlah heterofil darah perifer meningkat sesuai kebutuhan jaringan yang mengalami keradangan.

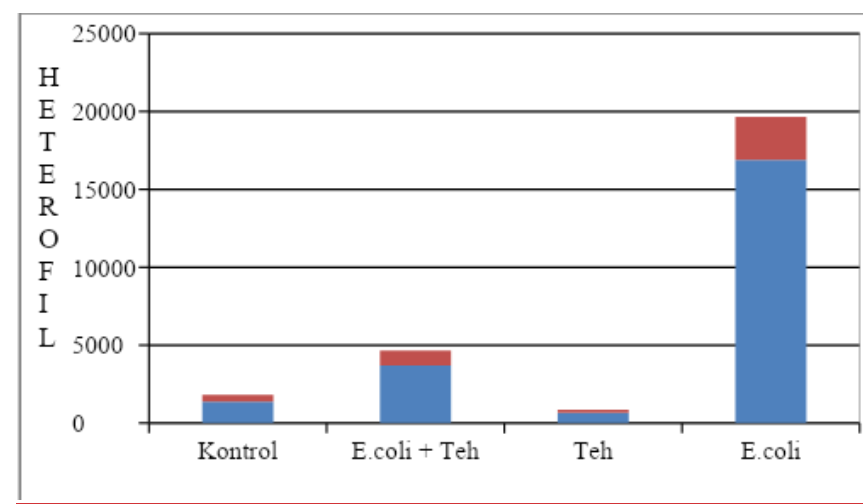

Gambar 3. Jumlah heterofil broiler 14 hari setelah infeksi Escherichia coli $10^{8} \mathrm{sel} / \mathrm{ml}$ standar Mc. Farland 0,5 dan diberi ekstrak daun teh hijau $0,1 \mathrm{~g} / \mathrm{ml}$ 
Penurunan jumlah heterofil pada ayam yang diberi ekstrak teh hijau $0,1 \mathrm{~g} / \mathrm{ml}$ setelah diinfeksi $E$. coli, menunjukkan peran ekstrak teh hijau yang berfungsi menghambat infeksi, sehingga tidak terjadi peradangan sebagai akibat aksi biologik teh hijau yang berperan dalam penurun lemak darah, anti radang, antimikrobia, anticancer, dan antioksidan, terkait dengan fraksi polifenol seperti catechin teh (Bohm, 1998; Jankun et al., 1997 dan Kumar et al., 2012) serta sebagai antiprotozoa (Paveto et al., 2004). Pada konsentrasi rendah epigallocatechin gallate dan epicatechin gallate dapat menekan faktor virulensi bakteri Staphylococcus aureus patogen oportunis yang resisten terhadap antibiotik $\beta$-lactam (Peter et al., 2005).

Monitoring keradangan secara umum pada hewan dan manusia masih menggunakan level total protein plasma (TPP) dan fibrinogen. Fibrinogen merupakan faktor koagulasi yang selalu dipertimbangkan saat fase akut dari proses infeksi, keradangan dan mekanisme lain seperti trauma (Davalos and Akassoglou, 2012). Konsentrasi TPP dan fibrinogen normal pada ayam masing-masing adalah 4,5 - 5,5 g/dL dan $0,1-0,4$ $\mathrm{g} / \mathrm{dL}$ (Feldman et al, 2000). Hasil pemeriksaan ayam perlakuan terhadap TPP tidak menunjukkan perbedaan nyata $(\mathrm{P}>0,05)$ diantara kelompok perlakuan, sedangkan hasil pemeriksaan kadar fibrinogen telah menunjukkan perbedaan yang signifikan diantara kelompok perlakuan $(\mathrm{P}<0,05)$, terutama ayam kelompok infeksi $E$. coli tanpa pemberian ektrak teh hijau (Tabel 3).

Semua kelompok perlakuan memiliki kadar TPP darah lebih rendah dari normal, meskipun kadar TPP ayam kelompok B ada kecenderungan memiliki kadar TPP lebih tinggi dibanding ayam kelompok C. Berbeda dengan kadar TPP, kadar fibrinogen secara keseluruhan cenderung meningkat dari normal. Peningkatan

Tabel 3. Rerata TPP dan fibrinogen broiler 14 hari setelah infeksi Escherichia coli $10^{8} \mathrm{sel} / \mathrm{ml}$ standar $M c$. Farland 0,5 dan diberi ekstrak daun teh hijau $0,1 \mathrm{~g} / \mathrm{ml}$

\begin{tabular}{lll}
\hline Perlakuan/Kelompok & $\begin{array}{l}\mathrm{TPP}(\mathrm{g} / \mathrm{dL}) \\
\mathrm{X} \pm \mathrm{sd}\end{array}$ & $\begin{array}{l}\text { Fibrinogen }(\mathrm{g} / \mathrm{dL}) \\
\mathrm{X} \pm \mathrm{sd}\end{array}$ \\
\hline Kontrol (A) & $2,80 \pm 0,61$ & $0,47 \pm 0,37^{\mathrm{a}}$ \\
E. coli (B) & $4,40 \pm 0,61$ & $1,93 \pm 0,47^{\mathrm{b}}$ \\
E. coli + Teh hijau (C) & $3,67 \pm 0,13$ & $0,83 \pm 0,09^{\mathrm{a}}$ \\
Teh hijau (D) & $3,33 \pm 0,24$ & $0,73 \pm 0,07^{\mathrm{a}}$ \\
\hline
\end{tabular}

${ }^{a, b}$ Huruf yang berbeda dalam kolom yang sama menunjukkan perbedaan yang signifikan $\mathrm{P}<0,05$ ) konsentasi fibrinogen terutama terjadi pada kelompok ayam B, yang hanya diinfeksi $E$. coli tanpa pemberian ekstrak teh hijau. Hal ini disebabkan karena respon fase akut dari keradangan akibat infeksi oleh bakteri (Roy et al., 2014), akan tetapi pemberian ekstrak teh hijau pada ayam yang diinfeksi E. coli menunjukkan konsentrasi TPP maupun fibrinogen darah lebih rendah dari ayam yang hanya diinfeksi $E$. coli saja.

\section{Kesimpulan}

Ekstrak teh hijau (Camelia sinensis) 0,1 g/ $\mathrm{ml}$ memiliki potensi menghambat infeksi bakteri Eschericia coli pada ayam broiler.

\section{Ucapan Terima Kasih}

Ucapan terimakasih disampaikan kepada Fakultas Kedokteran Hewan UGM atas pendanaan penelitian melalui BPPTN-BH FKH UGM 2018 dari Fakultas Kedokteran Hewan UGM dengan Nomor kontrak 1038./J01.1.22/HK4/2018.

\section{Daftar Pustaka}

Abalaka, S.E., sani, N.A., Idoko, I.S., Tenuche, O.Z., Oyelowo, F.O., Ejeh, S.A. and Enem, S.I. (2017). Pathological Changes Assosiated with An Outbreak of Colibacillosis in a Comercial Broiler flock. Sokoto Journal Of Veterinary Sciences 15 (3): 95 -102

Aggad, H., Ammar, Y.H., Hammoudi, A. and Kihal, M. (2010). Antimicrobial Resistance of Escherichia coli Isolated from Chickens with Colibacillosis. Global Veterinaria 4(3): 303-306

Akashi, N., Hitotsubashi, s., Yamanaka, H., Fujii, Y.,Tsuji,T., Miyama, A.,Juya, J.E. and Okamoto, K. (1993). Production of Heat Stabil Enterotoxin $\mathrm{H}$ by Chicken Clinical Isolates of Escherichia coli. Federation of European Microbiological Societies (FEMS) Microbiology Letters 109: 311-316

Akowuah, G.A., Ismail, Z., Norhayati, I., and Sadikun, A. (2005). The Effects of Different Extraction Solvents of Varying Polarities on Polyphenols of Orthosiphon Stamineus and Evaluation of the Free Radical-scavenging Activity. Journal of Food Chemistry, 93, 311-317.

Barnes, H.J. and Gross, W.B. (1997). Colibacillosis. In Disease of Poultry $10^{\text {th }}$ Ed. Iowa State University Press. Iowa. 
Bohm, B.A. (1998). Extraction, Purification and Identification of Flavonoids. In B. Ravindranath Ed. Introduction to Flavonoids. Harwood Academic Publishers, Vancouver, British Columbia, Canada. 175 - 241.

Chosa, H. Toda, M., Okubo, S., and Hara, Y. (1992). Anti Microbial and Microbicidal Activities of Tea and Catechins Againt Mycoplasma. Journal of The Japanese Association for Infectious Diseases 66: 606 - 611

Cook, J.K.A., Huggins, M.B., and Ellis, M.M. (1991). Use of an Infectious Bronchitis Virus and Escherichia coli Model Infection to Asses the Ability to Vacinate Sucessfully Against Infectious Bronchitis Virus in the Presence of Maternaly Derived Immunity. Avian Pathology 20: 619-626

Davalos, D and Akassoglou, K. (2012). Fibrinogen as Key Regulator of Inflamation in Disease. Seminar to immmunopathology $34: 43-62$

Dho-Moulin, M. and Fairbrother, J.M. (1999). Avian Pathogenic Escherichia coli (APEC), Veterinary Research. 30: 299-316

El-Tawab, A.A.A., Ammar, A.M., Nasef, S.A. and Reda, R.M. (2015). Prevalence of E.coli in Diseased Chickens with its Antibiogram Pattern. Benha Veterinary Medical Journal 28(2): 224 230

Feldman, B.F., Zinkl, J.G., Jain, N.B. (2000). Schalm's Veterinary Hematology. Fifth Ed. Lippincott William and Wilkins. A Wolter Kluwer Company. Pp 38 - 43, 163 - 167, 1147 - 1153

Gibbs, P.S., Petermann, S.R., and Wooley, R.E. (2004). Comparation of Several Challange Models for Studies in Avian Colibacillosis. Avian Disease 48: $751-758$

Goren, E. (1991). Observation on Experimental Infection of Chicks with Escherichia coli. Avian Pathology 7 : 213-224

Hertog, M., Feskens, E., Hollman, P., and Katan, M. (1993). Dietary Antioxidant fFavonoids and Risk of Coronary Heart Disease. The Zutphen Elderly Study. The Lancet 342: 1007 - 1011.

Hirasawa, M. and Takada, K. (2004). Multiple Effects of Green Tea Catechin on the Antifungal Activity of Antimycotics Againt Candida Albicans.
Journal of Antimicrobial Chemotheraphy 53: $225-229$.

Jankun, J., Selamn, S.H., and Swiercz, R. (1997). Why Drinking Green Tea Could Prevent Cancer. Nature 387: 833 - 838

Keli, S., Hertog, M., Feskens, E. and Kromhout, D. (1995). Flavonoids, Antioxidant Vitamins and Risk of Stroke. Archives of Internal Medicine 154: $637-642$

Kumar, A., Kumar, A., Thakur, P., Patil, S., Payal, C., Kumar, A. and Sharma, P. (2012). Antibacterial Activity of Green Tea (Camellia sinensis) Extracts Againt Various Bacteria Isolated from Environmental Sources. Recent Research in Science and Technology 4(1): 19 - 23

Majid, A., Ur Rahman, M.M., Shah, J.A., Khan, K., Ali, M.A., Zamin, I., Ulah, Z., Ibrar, M.and Zaman, Q. (2013). In Vitro Antibacterial Activity of Camellia sinensis Leaf Extracts to some Selective Pathogenic Bacterial Strains. International Journal of Biosciences 3(9): 69 $-75$

Matin, M.A., Islam, M.A. and Khatun, M.M. (2017). Prevalence of Colibacillosis in Chickens in Greater Mymensingh District of Bangladesh. Veterinary World 10 (1): 29 - 33

Mukti, A., Rastina, Haris, A., Ismail, Darniati, Masyitha, D. (2017). Resistensi Eschericia coli Terhadap Antibiotik dari Daging Ayam Broiler di Pasar Rukoh. Jurnal Ilmiah Mahasiswa Veteriner 01(3): 492- 498

Nakamura, K., Maeda, M., Imada, Y., Imada, T. and Sato, K. (1985). Pathology of Spontaneous Colibacillosis in Broiler Flock. Veteterinary Pathology 22: 592-597

Okubo, S., Toda, M., Hara, Y.,and Shimamura, T. (1991). Antifungal and Antifungicidal Activities of Tea Extract and Catechin Against Tricophyton. Japanese Journal of Bacteriology 46: 509 - 514

Ozaki, H. and Murase, T. (2009). Multiple Route of Entry for Escherichia coli Causing Colibacillosis in Comercial Layer Chicken. Journal of Veterinary Medicine Science 71(12) 1685-1689 
Padmini, E., Valarmathi, A., and Usha R. (2011). Comparative analysis of Chemical Composition and Antibacterial Activities of Mentha spicata and Camellia sinensis. Asian Journal of Experimental Biology Science 4: 772-778

Paveto, C., Guida, M.C., Esteva, M.I., Martino, V., Coussio, J., Flawia, M.M. and Torres, H.N. (2004). Anti Trypanosoma cruzi Activity of Green Tea (Camellia sinensis) Catechins. Antimicrobial Agent and Chemotherapy 48(1): $69-74$

Peter, W.T., Jeremy, M.T., And Poul, D.S. (2005). Antimicrobial Properties of Green Tea Cathecins. Food Science and Technology Bulletin 2: $71-81$

Rivero-Buceta E, Carrero P, and Doyaguez EG. (2015). Linear and Branched Alkyl-Esters and Amides of Gallic Acid and other (mono-, di- and tri-) Hydroxy Benzoyl Derivatives as Promising Anti-HCV Inhibitors. European Journal of Medical Chemistry 92:656-671.

Ronco, T., Stegger, M., Olsen, R.H., Sekse, C., Nordstoga, A.B., Pohjanvirta, T., Lilje, B., Andersen, P.S. and Pedersen, K. (2017). Spread of Avian Pathogenic Eschericia coli ST 117 O78:H4 in Nordic Broiler Production. BMC Genomic 18(3): 2 - 8

Roy, K., Bertelsen, M.F., Pors, S.E., Johansen, K.W., Kristensen, A.T., Kjelgaaed-Hansen, M., Andreasen, E.B., Christensen, J.P., Biswas, P.K. and Bojesen, A.M. (2014). Inflamation-induced Haemostatic Response In Layer Chickens Infected with Streptococcus equi subsp. Zooepidermicus as Evaluated by Fibrinogen, Protrombin Time and Thromboelastography. Avian Pathology 43(4): 364 - 370.
Sasongko, H. (2014). Uji Resistensi Bakteri Eschericia coli dari Sungai Boyong Kabupaten Sleman terhadap Antibiotik Amoksisilin, Kloramfenikol Sulfametoxasol, dan Streptomisin. http://www. researchgate.net/publication/319107630:2 - 17

Saif, Y.M., Barnes, J.R., Glisson, A.M., Fadly, L.R., McDougald and Swayne, D.E. (2003). Disease of Poultry $11^{\text {th }}$ ed., Iowa State University Press, Iowa.

Segneanu, A..E., Vlatanescu, N., Vaszilesin, C. And Macarrie, C.A. (2012). Antioxidant Capacity of Camellia sinensis extracts. Digest Journal of Nanomaterials and Biostructures 2: 729 -736

Weiss, D.J. and Wardrop, K.J. (2010). Schalm's Veterinary Hematology. Singapore. Blackwell

Whiteman, C.E., Bickford, A.A. and Barnes, H.J. (1989). Avian disease Manual, $3^{\text {rd }}$ ed. Dubuque, $1 \mathrm{~A}:$ Kendall/Hunt

Yamaguchi K, Honda M, Ikigai $\mathrm{H}$, Hara $\mathrm{Y}$, and Shimamura T. (2002). Inhibitory Effects of (-)-Epigallocatechin Gallate on the Life Cycle of Human Immunodeficiency Virus type 1 (HIV-1). Antiviral Research. 53:19-34

Yassin, A. K., Gong, J., Kelly, P., Lu, G., Guardabassi, L., Wei, L., Han, X., Qiu, H., Price, S., Cheng, D. and Wang, C. (2017). Antimicrobial Resistance in Clinical Eschericia coli Isolates from Poultry and Livestock, China. http://journals.plos.org/ plosone/article? $i d=10.1371$ : $1-5$

Zhao, S., Maurer, J.J., Hubert, S., DeVillena, J.F., McDermott, P.F., Meng, J., Ayers, S., English, 1., and White, D.G. (2005). Antimicrobial Susceptibility and Molecular Characterization of Avian Pathogenic Escherichia coli Isolates. Veterinary Microbiology 107: 218 -224 